\title{
BRAF wt Allele
}

National Cancer Institute

\section{Source}

National Cancer Institute. BRAF wt Allele. NCI Thesaurus. Code C51194.

Human BRAF wild-type allele is located within 7q34 and is approximately $190 \mathrm{~kb}$ in length.

This allele, which encodes B-Raf proto-oncogene serine/threonine-protein kinase protein,

plays a role in the transduction of mitogenic signals from the cell membrane to the nucleus. A specific activating somatic mutation in the BRAF gene is associated with several types of cancer such as colorectal and thyroid carcinomas and malignant melanoma. 